\title{
Correction of partial volume effect in SPECT
}

\section{金沢大学医学部附属病院 ○松平正道 ・ 山田正人 \\ (Masamichi Matsudaira) (Masato Yamada) \\ - 西田㥧一 \\ 飛坂 実 \\ (Minoru Tobisaka)}

【目的】SPECTなどの核医学画像はガンマカメラの低い空間分解能のため部分容皘効果の影幚を受け、小容 秚RI分布の值を正確に定量することができない。今回、planar画像やSPECT 画像（以下、RI画像）における 部分容䖽効果の補正法を考察し検討した。

【方法】得られたRI西像Do(x,y)に空間フィル夕処理を施すことにより、そのフィルタ特性とRI 四像に依存 したフィル夕处理画像が得られる。2種類の空間フィルタ $\mathrm{F} 1(\mathrm{X}, \mathrm{Y})$ および $\mathrm{F} 2(\mathrm{X}, \mathrm{Y})$ を施した画像D $1(\mathrm{x}, \mathrm{y})$ およ びD2 $(x, y)$ を作成して、雨者の除算画像テー夕 $f(x, y)$ を求める。次式に示すとおり $\mathbf{k f}(x, y)^{n}$ を元画像Do $(x, y)$ に 乗ずることにより補正画像 $\mathrm{D} c(x, y)$ を得た。フィルターには低域通遇型（単純移動平均および荷重移動平均） を用いた。

$$
\begin{aligned}
& \mathrm{D} 1(\mathbf{x}, \mathrm{y})=\mathrm{D} \circ(\mathbf{x}, \mathrm{y}) * \mathrm{~F} 1(\mathrm{X}, \mathrm{Y}) \\
& \mathrm{D} 2(\mathrm{x}, \mathrm{y})=\mathrm{D} \circ(\mathrm{x}, \mathrm{y}) * \mathrm{~F} 2(\mathrm{X}, \mathrm{Y})
\end{aligned}
$$

$$
\begin{aligned}
& f(x, y)=D_{1}(\mathbf{x}, y) / D_{2}(x, y) \\
& \operatorname{Dc}(\mathbf{x}, y)=D_{0}(\mathbf{x}, y) \times k f(x, y)^{n}
\end{aligned}
$$

planar面像Do(x,y)においては直径1.8、2.8、5.0、7.0、10.0、15.0、20.0、30.0、50.0 mmの円形線源（放射 能湦度均等な $\left.{ }^{99 \mathrm{~m}} \mathrm{Tc}\right)$ を、SPECT像Do(x,y)においては直径 $20 \mathrm{~cm}$ の水ファントム中に6、9、13、16、20、30、

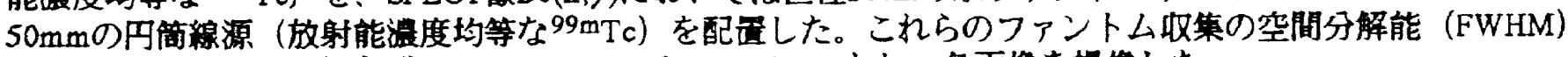

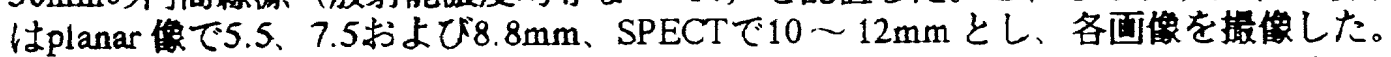

【結果】各画像の定量性をthreshold 70\%ROIの平均ビクセルカウントで評価した。直径 $50 \mathrm{~mm}$ (FWHMの4.5 〜9倍) 伴のカウントを1.0で規格化して表すと、何れの画像においてもFWHMの3.5 倍程度の大きさ以下の 線源匹像でクセルカウントの低下が慧められた。またplanar画像ではFWHMの約1.1倍の大きさの線源画像 でビクセルカウントは 0.5 に低下した。SPECT四像ではFWHMの約1.35倍で同様に0.5に低下した。

(4) 式によりこれらの面像の豧正を試みた結果。 planar西像についてはn=3によりFWHMと等倍程度の 大きさの線源画像まで10\%以内の琶差で補正可能であった。しかし、FWHMの1.5 倍の大きさ付近で遇補正 の傾向が認められた。凡そFWHMの大きさ以下では、ある程度の補正は可能であったが補正不足は頭著と なった。SPECT画像では $\mathrm{n}=4$ 住よりFWHM程度以上の大きさで同栏に補正が可能であった。なお、kについ ては今回の処理結果では凡そ1 が暗当であった。Fig.1にFWHM5.5mm:planar像の元画像、補正遇程、補正四 像についてのROIカウント、Fig.2にSPECTの元面像および補正画傮を示す。

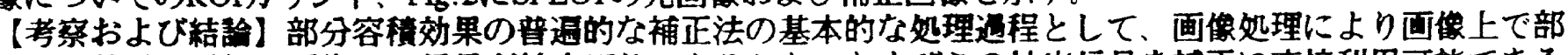
分容積効果に保わる画像 size信号が抽出可能であること、およびこの抽出信号を補正に直接利用可能である ことを目的として考察と実鈳的检討を進めてきた。補正法の方針とその可能性を示豆ことが出来たと考える

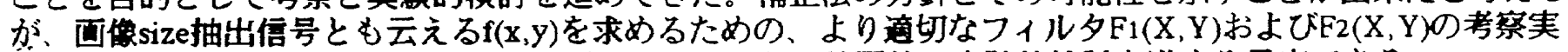

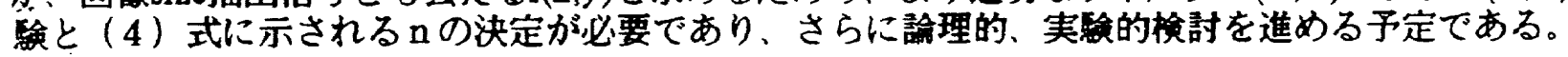

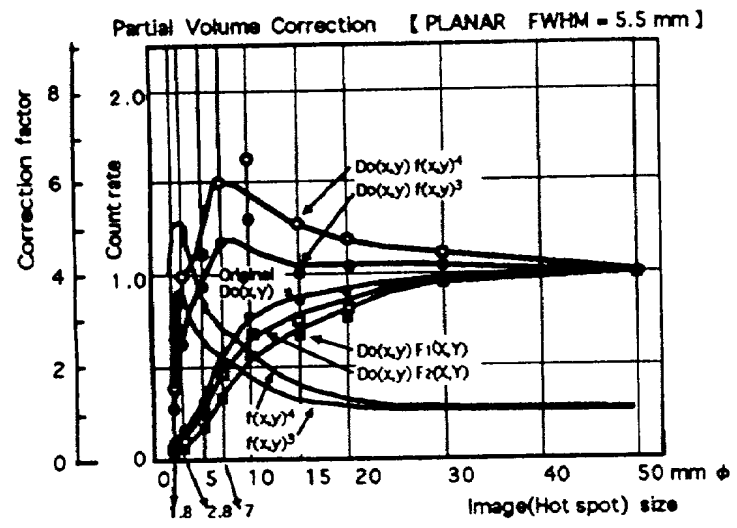

Fig. 1 元画像、補正保数 $(\mathrm{f}(\mathrm{x}, \mathrm{y}))$ 、補正画像のROIカウント
Partial Volume Effect correction SPECT

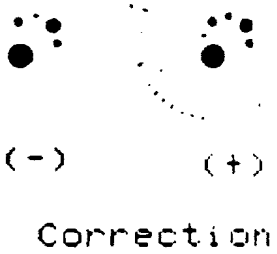

Fig.2 SPECTの元画像および補正画像 